\title{
Comparative Education In Canadian Universities
}

\author{
Marianne Larsen (University of Western Ontario), \\ Suzanne Majhanovich (University of Western Ontario), and \\ Vandra Masemann (OISE/University of Toronto)
}

\begin{abstract}
The first section of this article provides a brief overview of the field in Canada, and in so doing, demonstrates the broad nature of Comparative Education within the Canadian context. The second section of this article provides an overview of the comparative and international education programmes, specialization areas and courses in Canadian higher education institutions, focusing on three stages in the history of Comparative Education in Canada: the 1950s-1970s (Establishment of Comparative Education); the 1980s -1990s (Fragmentation of Comparative Education); and the 2000s (Broadening Comparative Education). While the focus in this article is on Comparative Education in graduate university programmes, a discussion about Comparative Education in teacher education is also included here. Two tables are presented which summarize changes in the field over the past 50 years and the titles of specific courses related to Comparative Education offered in Canadian universities. A discussion of the current state of Comparative Education in Canadian higher education follows with a few concluding explanatory comments about the current state of the field.
\end{abstract}

\begin{abstract}
Résumé
Dans la première partie de cet article nous offrons un panorama de ce champ au Canada, et en le faisant, nous démontrons la nature étendue de l'éducation comparée dans le contexte canadien. Dans la deuxième partie, nous donnons un aperçu sur les programmes, les domaines spécialisés, et les cours sur l'éducation comparée et internationale offerts dans les institutions d'études supérieures du Canada. Nous les donnons suivant les trois étapes de l'histoire de l'éducation comparée au Canada: pendant les décennies 1950-1970 (l'établissement de l'éducation comparée); pendant les décennies 1980-1990 (la fragmentation de l'éducation comparée); et dans les années 2000 (l'élargissement de l'éducation comparée). Le but principal de cet article est d'élaborer l'éducation comparée aux programmes d'études supérieures mais nous y parlons aussi de l'éducation comparée dans la formation des enseignants et des enseignantes. Deux tableaux donnent le sommaire des changements dans le domaine pendant les cinquante dernières années et le nom des cours offerts dans les universités canadiennes, ayant un trait spécifique avec l'éducation comparée. Nous présentons aussi l'état actuel de l'éducation comparée enseignée dans les universités canadiennes et terminons par quelques commentaires explicatifs sur l'état actuel de ce domaine d'étude.
\end{abstract}




\section{Overview of Comparative Education in Canada}

Any discussion of Comparative Education within Canadian higher education institutions must take into consideration the specific nature of the development of Comparative Education in Canada in relation to both pre-service teacher education and graduate programmes in the field. Historically, Comparative Education in Canada has been understood very broadly. This breadth was exemplified in both the content areas and the personnel who were considered to be members of the field. For example, according to the constitution of the Comparative and International Education Society of Canada (CIESC), first drafted in 1967, the following persons are eligible for membership:

Teachers, research workers, and graduate students in comparative education, international education, development education, native education, cross-cultural education, and related fields.

For many decades, discussions on what constitutes Comparative Education have occupied the minds of Canadian comparativists, as have their international counterparts. At the First World Congress of Comparative Education Societies held in Canada in 1970, Joseph Katz outlined his understanding of its compass in his Introduction to the Proceedings. He saw two major foci in the place of comparative education in the education of teachers and the role and rationale for educational aid to developing countries (Katz 1970).

Several Canadians delivered papers on the topic of the role of comparative education in teacher education, notably Douglas Ray, Margaret Gillett, Lionel Desjarlais, Andreas Paplauskas Ramunas, and Andrew Skinner. Desjarlais located his inspiration in the works of Michael Sadler, Isaac Kandel, Edmund King, and William Brickman and suggested a common thread in their definitions is a "philosophy of a human being in interaction with his environment" (Desjarlais 1970, p. 29). He proposed an undergraduate teacher education course in comparative education based on "a study of the pioneers of comparative education and the actual leaders in the field" followed by a study of national or regional systems in their social, economic, political and historical context (1970, p. 30). Douglas Ray concentrated on the mechanics of finding comparable data to present to students in such a course. The other speakers spent most of their time waxing philosophical about the intellectual underpinnings of such an endeavour.

In addition to the commonly accepted areas that are in the purview of comparative educationists, Canadian comparativisits have tended to include other less well-known areas as legitimate foci of research. For example, Binda (2001), past president of the CIESC, has argued a case for aboriginal education in Canada to be legitimized through comparative and global perspectives. As early as 1977 , multicultural education was being considered as a worthy topic of focus for comparativists, with the theme of the World Congress in London, (UK) being entitled Unity and Diversity in Education (Ray and Lamontagne, 1978). This 
theme has been taken up enthusiastically in Comparative Education in Canada since that time.

Moreover, given that education is a provincial and territorial responsibility in Canada, there are 13 different educational systems across the country. As a result, there is plenty of opportunity for comparative studies to include cross-regional comparisons within Canada. As Skinner (1972), one of Canada's earliest comparativists, pointed out, "Canada itself, within its own very extensive boundaries, offers wide scope and opportunity for enlightening comparative studies in education" (p. 5).

Further, one only need look at the articles published in the journal, Canadian and International Education, the official journal of the CIESC, to see the broad ways that Canadians view Comparative Education. Since 2000, the broad range of themes presented in journal articles include: citizenship education, globalization and marketization in educational reform, international development, bilingual education, Canadian and international assessments, and minority representation in curricular materials.

\section{Overview of Comparative Education in Canadian Higher Education Institutions}

a) Establishment of Comparative Education at Canadian Universities (1950s1970s)

The history of Comparative Education in Canada can actually be traced to the arrival of Issac Kandel and Peter Sandiford from Great Britain to Teachers' College at Columbia University, New York, in 1908. Five years later Sandiford, who wrote the 1918 text Comparative Education, moved from Columbia University to the University of Toronto in Canada where he taught in the Department of Education until 1941. Andrew Skinner from St. Andrews University in Scotland joined the staff of the Ontario College of Education ${ }^{2}$ at the University of Toronto in 1954. Skinner taught the history and philosophy of education and comparative education to teacher education students (in a postbaccalaureate programme) and to graduate students.

However, it was really not until the 1950s when Comparative Education spread across the country. Andreas Paplauskas-Ramunas migrated from Lithuania to head up the Centre of Comparative Education at the University of Ottawa in 1954. Two years later, Joseph Katz, who had attained his $\mathrm{PhD}$ at Chicago (1941) and who was the founder of the CIESC and first Canadian President of the U.S. based Comparative and International Education Society (CIES), had established Comparative Education at the University of British Columbia. Comparative Education was also initiated at McGill University in Montréal, Québec in 1960 by Reginald Edwards (London), another former CIESC president (Wilson, 1994a). 
In the late 1960s, we see the beginnings of Comparative Education in the provinces of Western Canada. McGill students, Daniel Dorotich and Werner Stephan founded the University of Saskatchewan programme. Two other comparative programmes were started up in the province of Alberta. Robert Lawson (Michigan) founded the programme at the University of Calgary, and Kazim Bacchus, John Cheal, and Raj Pannu initiated a programme at the University of Alberta (Wilson, 1994a).

In 1965, the Ontario Institute for Studies in Education (OISE), then affiliated with the University of Toronto and now a part of that university, was founded by legislation to provide graduate level programs, to conduct research and disseminate its findings, and to engage in field development activities in education. By 1968 two comparativists were hired, Joseph Farrell and David Wilson, in the then Department of Educational Planning. Courses in comparative education were taught in the Department of Sociology in Education. However, a formal programme in comparative and international education was not established until 1982 (Wilson, 1994b).

Comparative education was also established during the late sixties/early seventies at four other Canadian universities. Donald Weeren (Columbia) started up the programme at St. Mary's University in Halifax, Nova Scotia. Joseph Lauwerys, Professor of Comparative Education at the Institute of Education, University of London, became the founding director of the Atlantic Institute of Education in Halifax in 1970. The comparative programme at the Universite de Montréal (Québec) was founded by Marcel de Grandpré; and the programme at the University of Western Ontario in London, Ontario by Douglas Ray in the 1970s (Wilson, 1994a). Thus, by the 1970s there were eleven universities across the country with what could be called Comparative Education programmes or at least courses in Comparative Education within their education graduate programmes.

b) Fragmentation of Comparative Education in Canadian Universities (1980s 1990s)

Wilson (1994b) has argued that the programmes and offerings in the field of comparative education became fragmented in Canada by the 1990s. For example, by the end of the 1980s at the University of Ottawa and by the mid1990s at the University of British Columbia, Comparative Education programmes had virtually disappeared due to the retirement of key individuals associated with their founding. At an increasing number of universities, Comparative Education was reduced to what Wilson (1994b) calls "smaller programmes" with only one or two comparative courses and/or faculty in the field.

Comparative educators at these institutions were located in departments or programmes, where, according to Wilson, they primarily taught courses in their 
particular specialisations. Their comparative education courses appeared to be secondary to their primary teaching duties. Wilson (1994b) concludes that:

The "state" of our field in Canada can be described as fragmented in the light of this information. Most Canadian Comparative Educators are hired to teach courses other than Comparative Education and no stand-alone Department of Comparative Education exists in the country (p. 17).

There are a number of reasons to explain the fragmentation and decline of the field during this period. One could surmise that this change was due to the decline in the importance of the traditional foundations of education courses, such as History, Philosophy, and Comparative Education. This shift may also have been associated with internal re-arrangements of departments in institutions, in accordance with the move to more efficient administration of universities, based on a corporate model.

Cowen's (1990, p. 348) assertion that "the reputation of a particular university in comparative education was frequently linked with the efforts of one individual" is relevant with respect to the Canadian situation. With the retirement of some of those key individuals (e.g. Douglas Ray at the University of Western Ontario), we witnessed the demise of the programmes they had initiated.

Further, Wilson (1994b) also attributes the fragmentation of the field in Canadian universities to the fact that Comparative Education has not been "vested" in Provincial curriculum guidelines and is therefore largely absent from teacher preparation programmes at Faculties and Schools of Education. If there are comparative courses, they are generally optional or electives and when resources become scarce, as they did throughout the 1980s and 1990s, it was these courses that were often cut back or eliminated entirely from teacher preparation programmes.

\section{c) Broadening Comparative Education in Canadian Universities (2000s)}

Recent research has shown that to a large degree, Comparative Education in Canadian universities still remains fragmented. However, there is plenty of evidence that Comparative Education is on the rise and that comparative and international content and perspectives are being infused across many more educational graduate courses than has been the case in the past. Indeed, one might argue that over the last ten years or so, we have begun to witness a renaissance of Comparative Education in Canada. The impact of the process of globalization and increasing interest in international issues cannot be ignored. The hiring of a new generation of scholars is also fuelling this new fire.

With the exception of the 'hybrid' collaborative programme at the OISE/UT, which is discussed in further detail below, there are no stand-alone Comparative Education departments or even programmes in any Canadian 
universities. That being said, there are increasing numbers of universities with graduate degrees that include a focus area or specialization in comparative and international education, such as the focus area, domaine d'études: éducation comparée et fondements de l'éducation, available in the Masters and Doctoral programmes at the Université de Montréal. We can also see an increasing number of elective courses related to comparative and international education, and issues of globalization and cross-cultural learning/contexts that are being offered in Canadian universities.

Two tables are presented below to show the changes in Comparative Education over the last 50 years and current offerings of graduate courses related to comparative and international education. Specifically, Table 1 provides a summary of Canadian universities that have offered some kind of programme or courses in Comparative Education from the 1950s through to 2007. Table 2 provides a more detailed look at Comparative Education within Canadian universities today, listing Comparative Education courses and courses related to comparative and international education.

\section{d) Comparative Education in Teacher Education}

As noted above, the very early (pre-1950s) history of Comparative Education in Canada was largely connected to teacher education programmes, specifically in the Department of History, Philosophy and Sociology at the University of Toronto (UT). From the 1960s onwards, many new faculties and departments of education were established across the country, with a focus on teacher preparation. Traditionally programmes consisted of three parts: philosophy, pedagogy, and practice. Courses such as comparative education were offered within the philosophy (and sometimes historical) departments. For example, in the early years of the Ontario College of Education and then the Faculty of Education at the UT, Philosophy courses were expanded to include History, Sociology and Comparative Education. From 1967 onwards, there was an optional course in Comparative Education for students in the B.Ed. teacher preparation at the Faculty of Education at the UT.

Over time topics such as the philosophy and history of education, as well as comparative education, were offered across a range of teacher preparation programmes either within a compulsory Educational Foundations course or across a range of foundational courses from which students could choose. Comparative and international perspectives and topics are addressed in B.Ed. social foundations courses at McGill University, OISE/UT, Queen's University, University of Western Ontario, University of Manitoba and Simon Fraser University to name a few.

In addition, some teacher preparation programmes offer curriculum/pedagogy courses which incorporate comparative perspectives (e.g. 
Comparative Social Studies Education at the University of New Brunswick). Others are offering elective courses such as Global Education and Teaching for Global Justice and Peace (e.g. OISE/UT and the University of Ottawa) for their pre-service students, or a focus on global and human rights education within their elective curriculum courses (e.g. University of Western Ontario). In other cases, within some faculties of education, there are comparative education courses on topics such as citizenship, intercultural education, and comparative history of education (e.g. Universités de Montréal, Sherbrooke, Laval).

Further, with the emphasis on internationalization within higher education, there are increasing numbers of teacher preparation programmes that are promoting international practicum experiences for their students. Students preparing to become teachers at Queen's University in Ontario are encouraged to participate in the overseas practicum placement programme. Similarly, B.Ed. students at the University of Western Ontario may complete one week of an alternative practicum in an international setting. The University of Calgary offers a Teaching Across Borders international option for their B.Ed. Master of Teaching Program students. The Teaching Across Borders option:

can mean living living in another country and being affiliated with an institution there. It can also mean experiencing another way of life in [Canada] ...to enrich [students'] understanding and teaching ability through learning about another culture with deliberate focused study (Teaching Across Borders brochure).

Overall, similar to the situation at the graduate level, there are no standalone Comparative Education programmes or departments at the undergraduate, teacher preparation level. However, after the merger of the Faculty of Education and OISE in 2004, a new Comparative Education course was developed for teacher candidates in addition to the new curriculum course in Global Education mentioned above. This is an exception though, but perhaps indicates a shift in thinking about the importance of comparative and international education, in the preparation of teachers in an increasingly globalized world.

\section{Discussion}

Table 1 shows the number of universities that have had Comparative Education courses or programmes over the last 50 years or so. A quick count demonstrates that there were 10 (or 11 if we separate out the University of Toronto and the OISE) universities that developed Comparative Education programmes between the 1950s and 1970s. Available data from Wilson (1994a, 1994b), research by Zhang and Majhanovich (2006), and research for this article reveals that since the early 1990s there have consistently been 24 Canadian 
universities offering courses in Comparative Education. However, one must be cautious in concluding that there has been little change in the field over the past decade.

Table 2 provides us with more detail about the specific graduate programmes offered at Canadian universities that include comparative and international education content. The first column lists the university and programme degree names, the middle column lists the courses with the words 'Comparative Education' or 'Éducation Comparée' in their title, and the third column provides a list of courses that have the words 'comparative', 'international', 'global' or similar terms in their course descriptions. These latter point to the conclusion that these courses, while not at first glance on the topic of Comparative Education, include comparative and international education content and/or perspectives.

One institution that stands out amongst the others is the OISE/University of Toronto, which has had a long history in Comparative Education. Currently, OISE/UT offers a collaborative 'Comparative, International and Development Education' (CIDE) Programme that requires registration in one of the four OISE/UT main departments, a compulsory core course in Comparative, International and Development Education, and two other courses that meet the CIDE requirement, as well as the other required departmental courses for the degree. In this respect, OISE is perhaps not a stand-alone programme, but a hybrid - a formally recognized programme that acts as a specialization with their graduate degree. $^{3}$

Most other Canadian universities offer Comparative Education courses under the umbrella of a wide variety of different programmes. In these cases, students are enrolled in graduate programmes such as Policy Studies or Adult Education and then they can focus or specialize in Comparative Education. For example, the University of British Columbia offers two M.Ed. degrees in Adult Education/Learning has four courses related to comparative and international education. The University of Alberta offers an M.A. in Education Policy Studies with specialization in International Studies in Education. There are nine courses in this program that are related to comparative and international education. At McGill, comparative perspectives are integrated into their "Culture and Values" graduate programmes, while at St. Mary's University students are expected to take the compulsory Introduction to Comparative Education as a part of the Masters of TESL (Teaching English as a Second Language) and TEFL (Teaching English as a Foreign Language) programmes. 
TABLE 1

\section{Canadian Universities with Comparative Education Graduate Courses}

\begin{tabular}{|c|c|c|c|c|}
\hline & $\begin{array}{l}\text { 1950s- } \\
1970 \text { s }\end{array}$ & 1994 & 2002 & 2007 \\
\hline UNIVERSITY & $\begin{array}{l}\text { Data from } \\
\text { Wilson } \\
\text { (1994a) }\end{array}$ & $\begin{array}{l}\text { Data from } \\
\text { Wilson } \\
\text { (1994b) }\end{array}$ & $\begin{array}{l}\text { Data from } \\
\text { Zhang and } \\
\text { Majhanovic } \\
\mathrm{h}(2006)\end{array}$ & \\
\hline Brandon University & & 1 & 2 & 2 \\
\hline Brock University & & 1 & 1 & 4 \\
\hline Concordia University & & 2 & 2 & 2 \\
\hline Dalhousie University & & 2 & 2 & 0 (no program) \\
\hline Lakehead University & & 1 & 1 & 1 \\
\hline McGill University & $\sqrt{ }$ & 4 & 2 & 2 \\
\hline Memorial University & & 2 & 2 & 2 \\
\hline Queen's University & & 1 & 1 & 2 \\
\hline St. Mary's University & $\sqrt{ }$ & 6 & 0 & 2 \\
\hline Simon Fraser University & & 0 & 0 & 4 \\
\hline Université de Sherbrooke & & 4 & 0 & 1 \\
\hline Université de Montréal & $\sqrt{ }$ & 9 & NA & 2 \\
\hline $\begin{array}{l}\text { Université du Québec (Hull) } \\
\text { U. Q. (Trois Rivières) } \\
\text { U. Q (Chicoutimi) } \\
\text { U. Q. (Montrèal) }\end{array}$ & & $\begin{array}{l}1 \\
1 \\
1 \\
1 \\
\end{array}$ & $\begin{array}{l}1 \\
0 \\
1 \\
1 \\
\end{array}$ & $\begin{array}{l}0 \\
0 \\
1 \\
2 \\
\end{array}$ \\
\hline Université Laval & & 0 & 0 & 1 \\
\hline University of Alberta & $\sqrt{ }$ & 5 & 3 & 10 \\
\hline University of British Columbia & $\sqrt{ }$ & 1 & 4 & 4 \\
\hline University of Calgary & $\sqrt{ }$ & 2 & 1 & 10 \\
\hline University of Manitoba & & 3 & 3 & 2 \\
\hline University of New Brunswick & & 1 & 1 & 0 \\
\hline University of Ottawa & $\sqrt{ }$ & 0 & NA & 4 \\
\hline University of Regina & & 2 & 2 & 0 \\
\hline University of Saskatchewan & $\sqrt{ }$ & 1 & 1 & 3 \\
\hline University of Toronto/OISE & $\sqrt{ }$ & 12 & 12 & 23 \\
\hline University of Victoria & & $\mathrm{NA}$ & 1 & 1 \\
\hline University of Western Ontario & $\sqrt{ }$ & 2 & 5 & 6 \\
\hline University of Windsor & & NA & 0 & 1 \\
\hline York University & & NA & NA & 3 \\
\hline
\end{tabular}




\section{TABLE 2}

Canadian Universities with Comparative Education Graduate Courses

Course and Program Details - 2007

\begin{tabular}{|c|c|c|}
\hline $\begin{array}{ll}\text { UNIVERSITY } & \text { AND } \\
\text { PROGRAMME/ } & \\
\text { DEGREE NAME } & \end{array}$ & $\begin{array}{l}\text { Title of course contains } \\
\text { "Comparative Education" or } \\
\text { "Éducation Comparée" }\end{array}$ & $\begin{array}{l}\text { Course description contains } \\
\text { words: } \\
\text { Comparative, International or } \\
\text { similar }\end{array}$ \\
\hline \begin{tabular}{lr}
\multicolumn{3}{l}{ Brandon University } \\
- M.Ed in & Educational \\
Psychology & and \\
Foundations & \\
\end{tabular} & $\begin{array}{l}\text { - Comparative Education I } \\
\text { - Comparative Education II }\end{array}$ & \\
\hline $\begin{array}{l}\text { Brock University } \\
\text { - M.Ed. }\end{array}$ & $\begin{array}{l}\text { Comparative Studies of } \\
\text { Education in Developed and } \\
\text { Developing Nations }\end{array}$ & $\begin{array}{l}\text { - Holistic/Global Perspectives in } \\
\text { Education } \\
\text { - International Education } \\
\text { - The Accountability Challenge }\end{array}$ \\
\hline \begin{tabular}{l}
\multicolumn{3}{l}{ Concordia University } \\
- M.A. in Education with \\
topic of study in \\
comparative \\
intercultural education
\end{tabular} & & $\begin{array}{l}\text { - The Education of Immigrants } \\
\text { and Minorities } \\
\text { - Selected Topics in Education: } \\
\text { Literacy in Cross-Cultural } \\
\text { Perspective \& Democratic } \\
\text { Education }\end{array}$ \\
\hline $\begin{array}{l}\text { Lakehead University } \\
\text { - M.Ed. }\end{array}$ & $\begin{array}{l}\text { History and Comparative } \\
\text { Education }\end{array}$ & \\
\hline $\begin{array}{l}\text { McGill University } \\
\text {-M.A. in Culture and } \\
\text { Values } \\
\text {-PhD. with specialization in } \\
\text { Cultural and International } \\
\text { Studies in Education }\end{array}$ & & $\begin{array}{l}\text { - Culture, Values and Education } \\
\text { - Globalization, Education and } \\
\text { Change }\end{array}$ \\
\hline $\begin{array}{l}\text { Memorial University of } \\
\text { Newfoundland } \\
-\quad \text { M.Ed. (Leadership } \\
\text { Studies) }\end{array}$ & $\begin{array}{l}\text { - Comparative Perspectives in } \\
\text { Public Education, Reform and } \\
\text { Leadership }\end{array}$ & \\
\hline $\begin{array}{l}\text { Queen's University } \\
\text { - M.Ed. and PhD (Cultural } \\
\text { and Policy Studies) }\end{array}$ & $\begin{array}{l}\text { - Comparative, International and } \\
\text { Development Education }\end{array}$ & - Globalization and Education \\
\hline $\begin{array}{l}\text { St. Mary's } \\
\text { - M.A. of TESL and TEFL } \\
-\quad \text { M.A. International } \\
\text { Development Studies }\end{array}$ & $\begin{array}{l}\text { - Introduction to Comparative } \\
\text { Education }\end{array}$ & $\begin{array}{l}- \text { Sociology of Developing } \\
\text { Societies } \\
-\quad \text { Gender, Ethnicity and } \\
\text { Migration } \\
-\quad \text { Philosophical Issues in } \\
\text { International Development } \\
\text { - Special Topics in International } \\
\text { Development }\end{array}$ \\
\hline $\begin{array}{l}\text { Simon Fraser University } \\
- \text { M. Ed. in TEFL/TESL } \\
\text { for international educators } \\
- \text { M.Ed and Ph.D in } \\
\text { Educational Leadership }\end{array}$ & $\begin{array}{l}\text { - Introduction to Comparative } \\
\text { Education } \\
\text { - Educational Governance, } \\
\text { Reform and Diversity } \\
\text { - Curriculum and Instruction: } \\
\text { Teaching in an ESL Context } \\
\text { "Dalian China" }\end{array}$ & $\begin{array}{l}\text { - Equity Issues in Language and } \\
\text { Literacy Education }\end{array}$ \\
\hline Université de Sherbrooke & & $\begin{array}{l}\text { - Pratiques internationales en } \\
\text { gestion de la formation }\end{array}$ \\
\hline
\end{tabular}




\begin{tabular}{|c|c|c|}
\hline $\begin{array}{l}\text { Université du Montréal } \\
-\quad \text { M. Ed. and Doctoral } \\
\text { Focus: } \\
\text { Education }\end{array}$ & $\begin{array}{l}\text { - Option éducation comparée et } \\
\text { fondements de l'éducation }\end{array}$ & \\
\hline $\begin{array}{l}\text { Université du Québec à } \\
\text { Chicoutimi (UQAC) }\end{array}$ & & $\begin{array}{l}\text { - Éducation à la citoyenneté } \\
\text { dans le domaine de l'univers } \\
\text { social }\end{array}$ \\
\hline $\begin{array}{l}\text { Université du Québec à } \\
\text { Montréal }\end{array}$ & - Éducation comparée & - Éducation interculturelle \\
\hline Université Laval & $\begin{array}{l}\text { - Aspects internationaux et } \\
\text { comparatifs de l'éducation }\end{array}$ & \\
\hline $\begin{array}{l}\text { University of Alberta } \\
\text { - M.A. in Ed Policy Studies } \\
\text { with specialization in } \\
\text { International Studies in } \\
\text { Education }\end{array}$ & $\begin{array}{l}\text { - Foundations of Education: } \\
\text { Perspectives on International } \\
\text { Issues }\end{array}$ & $\begin{array}{l}\text { - International Adult Education } \\
\text { - Education and Development } \\
\text { Theory } \\
\text { - History of Education } \\
\text { - Sociology of Higher Education } \\
\text { - Citizenship Education: Global } \\
\text { Contexts } \\
\text { - Contemporary Issues in } \\
\text { Education } \\
\text { - Global Education: Theory and } \\
\text { Practice } \\
\text { - Policy Analysis in Education } \\
\text { - Indigenous Ontologies in the } \\
\text { Global Context }\end{array}$ \\
\hline $\begin{array}{l}\text { University of British } \\
\text { Columbia } \\
\text { - M.Ed. in Adult Education } \\
\text { - M.Ed. in Adult Learning } \\
\text { and Global Change- online }\end{array}$ & & $\begin{array}{l}\text { - Comparative and International } \\
\text { Adult and Higher Education } \\
\text { - Online: Locating Oneself in } \\
\text { Global Learning } \\
\text { Adult Learning: Contexts and } \\
\text { Perspectives } \\
\text { - Global-Local Learning }\end{array}$ \\
\hline \begin{tabular}{lr}
\multicolumn{2}{l}{ University of Calgary } \\
- M.A. (specializations in \\
Educational & Contexts; \\
Educational & Leadership; \\
Higher & Education \\
Administration) &
\end{tabular} & & $\begin{array}{l}\text { - Educational Leadership in } \\
\text { Changing Contexts } \\
- \text { Issues in Social Justice } \\
\text { Research } \\
- \text { Cultures, Identity and } \\
\text { Schooling } \\
\text { - Struggle for Democracy } \\
- \text { Values Debate \& Young } \\
\text { People } \\
\text { - Education, Globalization \& } \\
\text { Revolution } \\
\text { - Women in Education } \\
\text { - Critical Pedagogy and Social } \\
\text { Justice } \\
- \text { Social Justice Activism in } \\
\text { Education } \\
\text { - Issues in First Nations } \\
\text { Education }\end{array}$ \\
\hline $\begin{array}{l}\text { University of Manitoba } \\
\text { - M. Ed. in Educational } \\
\text { Administration, } \\
\text { Foundations and Ed } \\
\text { Psychology }\end{array}$ & - Comparative Education & - Cross-cultural Education \\
\hline $\begin{array}{l}\text { University of Ottawa } \\
-\quad \text { M.A./M.Ed. with } \\
\text { concentration in "Society, }\end{array}$ & 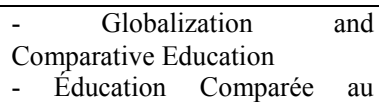 & $\begin{array}{l}\text { - Education of Marginalized } \\
\text { Youth } \\
\text { - Ethnography of Education }\end{array}$ \\
\hline
\end{tabular}

Education canadienne et internationale Vol. 36 n $^{\circ} 3$ - décembre 200725 


\begin{tabular}{|c|c|c|}
\hline $\begin{array}{l}\text { Culture and Literacies" } \\
\text { - M.A. of Globalization and } \\
\text { International Development }\end{array}$ & Canada & \\
\hline $\begin{array}{l}\text { University of Saskatchewan } \\
-\quad \text { M.Ed. } \\
\text { Foundations) }\end{array}$ & $\begin{array}{lll}- & \text { Comparative } & \text { Studies in } \\
\text { Education } & \end{array}$ & $\begin{array}{l}\text { - Comparative Continuing } \\
\text { Education } \\
\text { - Interdisciplinary Seminar in } \\
\text { the Foundations of Education }\end{array}$ \\
\hline $\begin{array}{l}\text { University } \\
\text { Toronto/OISE } \\
\text { - M.A., M.Ed. and Ph.D } \\
\text { with specialization in } \\
\text { Comparative, International } \\
\text { and Development } \\
\text { Education }\end{array}$ & $\begin{array}{l}\text { - Introduction to Comparative, } \\
\text { International, and Development } \\
\text { Education } \\
-\quad \text { Special Topics in } \\
\text { Comparative, International and } \\
\text { Development Education } \\
\text { - Comparative Education } \\
\text { Theory and Methodology } \\
\text { - Methodologies for Comparing } \\
\text { Educational Systems } \\
\text { - Comparative Higher } \\
\text { Education }\end{array}$ & 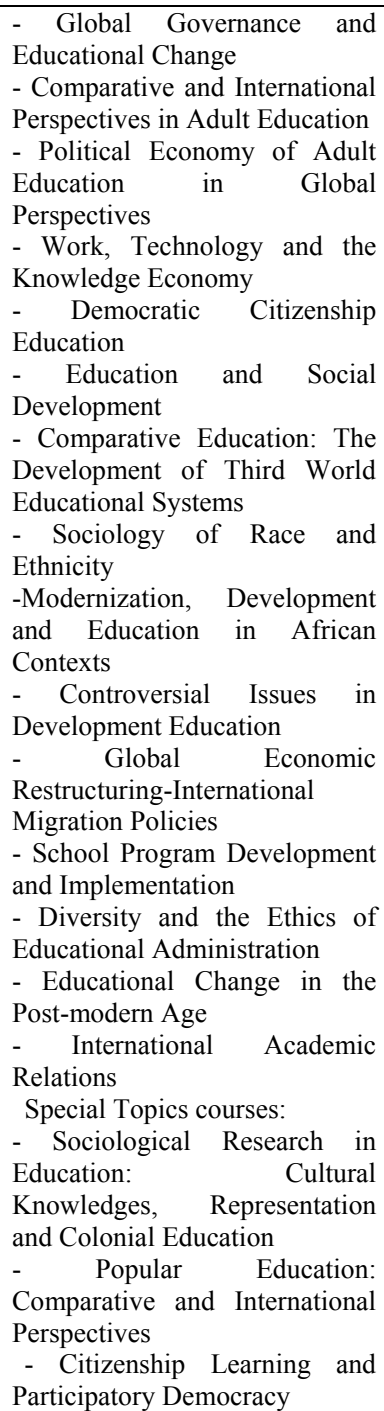 \\
\hline $\begin{array}{l}\text { University of Victoria } \\
\text {-M.Ed/M.A. in Educational } \\
\text { Psychology and Leadership } \\
\text { Studies }\end{array}$ & $\begin{array}{l}\text { - Comparative Perspectives on } \\
\text { Organizational Leadership }\end{array}$ & \\
\hline $\begin{array}{l}\text { University of Western } \\
\text { Ontario } \\
\text { - M.Ed. (Policy Studies) }\end{array}$ & $\begin{array}{l}\text { - Introduction to Comparative } \\
\text { Education }\end{array}$ & $\begin{array}{l}\text { - Globalization and Educational } \\
\text { Restructuring } \\
\text { - Minority Language Issues }\end{array}$ \\
\hline
\end{tabular}




\begin{tabular}{|l|l|l|}
\hline & & $\begin{array}{l}\text { - Language and Education } \\
- \text { Mathematics, Science, and } \\
\text { Technology Education: Policy } \\
\text { and Society the } \\
-\quad \text { Perspectives on the } \\
\text { Environment: Global Education } \\
\text { in a Technological Society }\end{array}$ \\
\hline $\begin{array}{l}\text { University of Windsor } \\
\text { - M.A. (Education) }\end{array}$ & $\begin{array}{l}\text { - Special Topics in Education: } \\
\text { Comparative and International } \\
\text { Education }\end{array}$ & $\begin{array}{l}\text { - Issues in Globalization and } \\
\text { Education } \\
\text { - Women in Higher Education } \\
\text { - Multilingual Education }\end{array}$ \\
\hline $\begin{array}{l}\text { York University M.Ed.. (Language, } \\
\text { Culture and Teaching) }\end{array}$ & & \\
\hline
\end{tabular}

This pattern illustrates the broad interpretation of comparative education within Canada that was discussed above. We can also find evidence of this by examining the types of graduate courses that include Comparative Education perspectives and content. Comparative perspectives and content are included in courses related to ethnicity/race/culture (multiculturalism and intercultural education), reflecting the particular Canadian comparative emphasis of these topics. Other related topics addressed from comparative perspectives include language/literacy education, indigenous/First Nations education and gender. Furthermore, we see rising numbers of courses that include comparative and international perspectives on topics such as education policy, higher education, adult education, leadership and educational administration, citizenship and global education. Globalization is another increasingly popular topic at the graduate level, and a handful of institutions, such as OISE/UT and St. Mary's, have courses on development and education, and education in developing societies. In other cases, within some faculties of education there are comparative undergraduate courses on topics such as citizenship, inter-cultural education, and the history of education (e.g. Université de Montréal, Sherbrooke, and Laval ).

Finally, it is worth considering some of the methodological problems in attempting to carry out research such as this. Without knowing the specific criteria that Wilson (1994a, 1994b) used to determine whether or not a university offered a Comparative Education programme, it is difficult to draw conclusions between his data and more recent data. This raises the question of what constitutes a formal programme. This article has taken a broader approach in examining the state of Comparative Education within Canadian higher education by considering not simply formal stand-alone programmes, but also Comparative Education courses and those within which are infused comparative and international education content and perspectives. However, this in itself is difficult to determine because course titles and descriptions are often out of date on university web-sites and/or do not reflect what is taught by individual instructors. Discussions with Canadian comparativists regarding this situation have led the authors to conclude that there 
are likely many more courses beyond those included in Table 2 that include within them comparative perspectives and content.

\section{Conclusion}

This article has reviewed some of the changes in the field of Comparative Education in Canadian higher education since the early twentieth century. There have been three main phases: the first from the 1950s up until the 1970s which witnessed the establishment of Comparative Education in Canadian universities; the second from the 1980s-1990s when the field became fragmented, and the current phase (2000-) in which the field has been broadened. Today, while there are no formal, stand-alone programmes in Comparative Education within Canada there is plenty of evidence to suggest that comparative and international perspectives are being infused across a wide variety of graduate programmes and courses.

The very early history of comparative education was largely connected to teacher education programmes. This article, however, has focused primarily on Comparative Education within graduate programmes. OISE/UT is the only Canadian university that has a Comparative Education program, albeit a 'hybrid' one. Further, it appears as though there are only ten universities that offer traditional courses in Comparative Education methodologies and theories. We can posit that the trend towards devaluing theoretical and methodological issues in educational research with corresponding increasing emphasis on practical matters may have had some impact on types of graduate education courses offered in Canada and other settings such as Mexico, which Buenfil Burgos (1999) has examined.

Nonetheless, over the last ten years or so there has actually been an increase in courses that address their topics from a comparative and/or international perspective. In place of many traditional courses in Comparative Education theory and methodology, there are now courses that address issues such as international development, culture and values, citizenship education, global education, higher education, adult education and indigenous education from comparative and international perspectives.

Even if hired for other purposes, comparativists have continued to infuse the courses they offer with international/comparative content. Indeed, an increasing number of comparativists have been hired in Canadian universities. A partial list of active comparativists across Canada who have entered the field since the 1980s includes: Alan Sears at the University of New Brunswick; Marie Mc Andrew at l'Université de Montréal; Eva Krugly-Smolska at Queen's University; Richard Maclure at the University of Ottawa; Karen Mundy, Ruth Hayhoe, and Daniel Schugurensky at the OISE/UT; Goli Rezai-Rashti and Marianne Larsen at the 
University of Western Ontario; Nombuso Dlamini at the University of Windsor; Cecille DePass and Yvonne Hébert at the University of Calgary; Ali Abdi at the University of Alberta; and Peter Grimmett at Simon Fraser University.

On a concluding note, new collaborative partnership programmes with universities in other countries can also be considered evidence of the rise of comparative and international education. Some universities are also internationalizing their curriculum, offering more study abroad programmes, and increasing their intake of international graduate students. These initiatives, related to trends such as globalization and the internationalization of higher education (Ninnes and Hellstén, 2005), may be having an impact on the field of Comparative Education in Canada. The Faculty of Education at the University of Western Ontario, for example, is planning to re-establish its formal Comparative Education programme to align with wider strategic plan goals related to internationalization of the university.

\section{Notes:}

We would like to acknowledge the work of two graduate students at the UWO, Faculty of Education who did research for this article: Lanlin Zhang and Mohsen Mahmoudi.

1. This article was originally published as a chapter in Wolhuter, C. \& Popov, N. (Eds.) (2007) Comparative Education as Discipline at Universities World Wide. Sofia: Bureau for Educational Services. We would like to thank the editors for having graciously given us the permission to publish this article in this issue of the Journal. An additional section on Comparative Education in teacher education has been included in this version.

2. The Faculty/Department of Education at the University of Toronto was renamed the Ontario College of Education (OCE) in 1920 and was the only secondary teacher preparation institution in the province for the next 45 years. In 1965, the Ontario Institute for Studies in Education (OISE) was founded and a year later, the Departments of Graduate Studies and Research were transferred from the OCE to the OISE, while teacher education remained at the U of T. In 2004, the U of T Faculty of Education and the OISE merged and now exist as one institution, named OISE/UT.

3. Thank you, Dr. Karen Mundy, for clarifying this point. 


\section{References}

Binda, K. P. (2001): Aboriginal Education in Comparative and Global Perspectives: What has research and practice done for aboriginal education in Canada? Canadian and International Education, Vol.30, No.1, pp.1-16.

Buenfil Burgos, R.M. (1999) The Spectre of Theory in Curriculum for Educational Researchers: A Mexican Example. In Soudien, C., Kallaway, P, with Breier, M. (Eds.) Education, Equity and Transformation, Hamburg: UNESCO Institute for Education, pp.461-478.

Cowen, R. (1990): The National and International Impact of Comparative Education Infrastructures. In Halls, W.D. (ed.), Comparative Education: Contemporary Issues and Trends. London \& Paris: Jessica Kingsley \& UNESCO, pp.321-352.

Desjarlais, L. (1970): Organization of Courses. In Proceedings of the First World Congress of Comparative Education Societies on the Place of Comparative and International Education in the Education of Teachers. Ottawa, Canada: mimeographed, pp.28-30.

Katz, J. (1970): The Purpose, Plan and Program for the World Congress of Comparative Education Societies. In Proceedings of the First World Congress of Comparative Education Societies on the Place of Comparative and International Education in the Education of Teachers. Ottawa, Canada; mimeographed, pp.1-2.

Majhanovich, S. \& Zhang, L. (2007): The Comparative and International Education Society of Canada (CIESC). In Masemann,V., Bray, M. and Manzon, M. (eds.) Common Interests, Uncommon Goals: Histories of the World Council of Comparative Education Societies and its Members. Hong Kong \& Dordrecht: Comparative Education Research Centre, The University of Hong Kong and Springer, pp.170-182.

Ninnes, P. \& Hellstén, M. (eds.) (2005): Internationalizing Higher Education: Critical Explorations of Pedagogy and Policy. Hong Kong \& Dordrecht: Comparative Education Research Centre, The University of Hong Kong and Springer.

Ray, D. \& Lamontagne, J. (1978): Cultural Diversity and Political Unity. Abstracts from the Third World Congress of Comparative Education Societies. London, Ontario: University of Western Ontario.

Sandiford, P. (ed.) (1918): Comparative Education: Studies of the Educational Systems of Six Modern Nations. London, Toronto: J.M. Dent \& Sons Ltd.

Skinner, A. F. (1972): Transition: A Note for the Record. Canadian and International Education, Vol.1, No.1, pp.4-6.

Teaching Across Borders brochure. Accessed November 2006 from: http://www.educ1.ucalgary.ca/dtp/pdf/teaching_across.pdf )

Wilson, D. (1994a): Comparative and International Education: Fraternal or Siamese Twins? A Preliminary Genealogy of Our Twin Fields. Comparative Education Review, Vol.38, No.4, pp.449-486.

Wilson, D. (1994b): On Teaching the Methodology of Comparative Education: Why Are There So Few Courses in Canada? Canadian and International Education, Vol.23, No.1, pp.13-24.

Zhang, L. \& Majhanovich, S. (2006): A Journey of Exploration: A brief history of the CIESC. Unpublished draft version of Majhanovich and Zhang (2007). 
Marianne Larsen is an Assistant Professor at the Faculty of Education, the University of Western Ontario. She teaches Comparative Education at the graduate level. Current research interests include teacher policies and global citizenship education. She can be contacted at mlarsen@uwo.ca

Suzanne Majhanovich, former President of the CIESC, is a Professor at the Faculty of Education, the University of Western Ontario. Current research interests include international language policies, globalization and decentralization. She edits Canadian and International Education. She can be contacted at smajhano@uwo.ca

Vandra Masemann, former President of the CIES, is currently an Adjunct Associate Professor, Comparative and International Development Education Program, Ontario Institute for Studies in Education at the University of Toronto. She teaches the course, Introduction to Comparative, International and Development Education. Research interests include anthropological approaches in Comparative Education, multicultural and bilingual education. She can be contacted at masemann@interlog.com 